\title{
Interactive comment on "Mahalanobis distance based recognition of changes in the dynamics of seismic process" by Teimuraz Matcharashvili et al.
}

Teimuraz Matcharashvili et al.

matcharashvili@gtu.ge

Received and published: 29 March 2019

First of all we would express sincere gratitude to Prof. Papadimitriou for careful reading of our manuscript and highly competent and valuable remarks. Below we present reviewer's remarks, with our answers to them.

Please also note the supplement to this comment:

https://www.nonlin-processes-geophys-discuss.net/npg-2018-57/npg-2018-57-AC1-

supplement.pdf

Printer-friendly version

Discussion paper

Interactive comment on Nonlin. Processes Geophys. Discuss., https://doi.org/10.5194/npg2018-57, 2019. 